\title{
Self-Reconfigurable Robots: An Introduction
}

Stoy, Kasper; Brandt, David; Christensen, David Johan

Publication date:

2010

Link back to DTU Orbit

Citation (APA):

Stoy, K., Brandt, D., \& Christensen, D. J. (2010). Self-Reconfigurable Robots: An Introduction. MIT Press. Intelligent robotics and autonomous agents

\section{General rights}

Copyright and moral rights for the publications made accessible in the public portal are retained by the authors and/or other copyright owners and it is a condition of accessing publications that users recognise and abide by the legal requirements associated with these rights.

- Users may download and print one copy of any publication from the public portal for the purpose of private study or research.

- You may not further distribute the material or use it for any profit-making activity or commercial gain

- You may freely distribute the URL identifying the publication in the public portal

If you believe that this document breaches copyright please contact us providing details, and we will remove access to the work immediately and investigate your claim. 


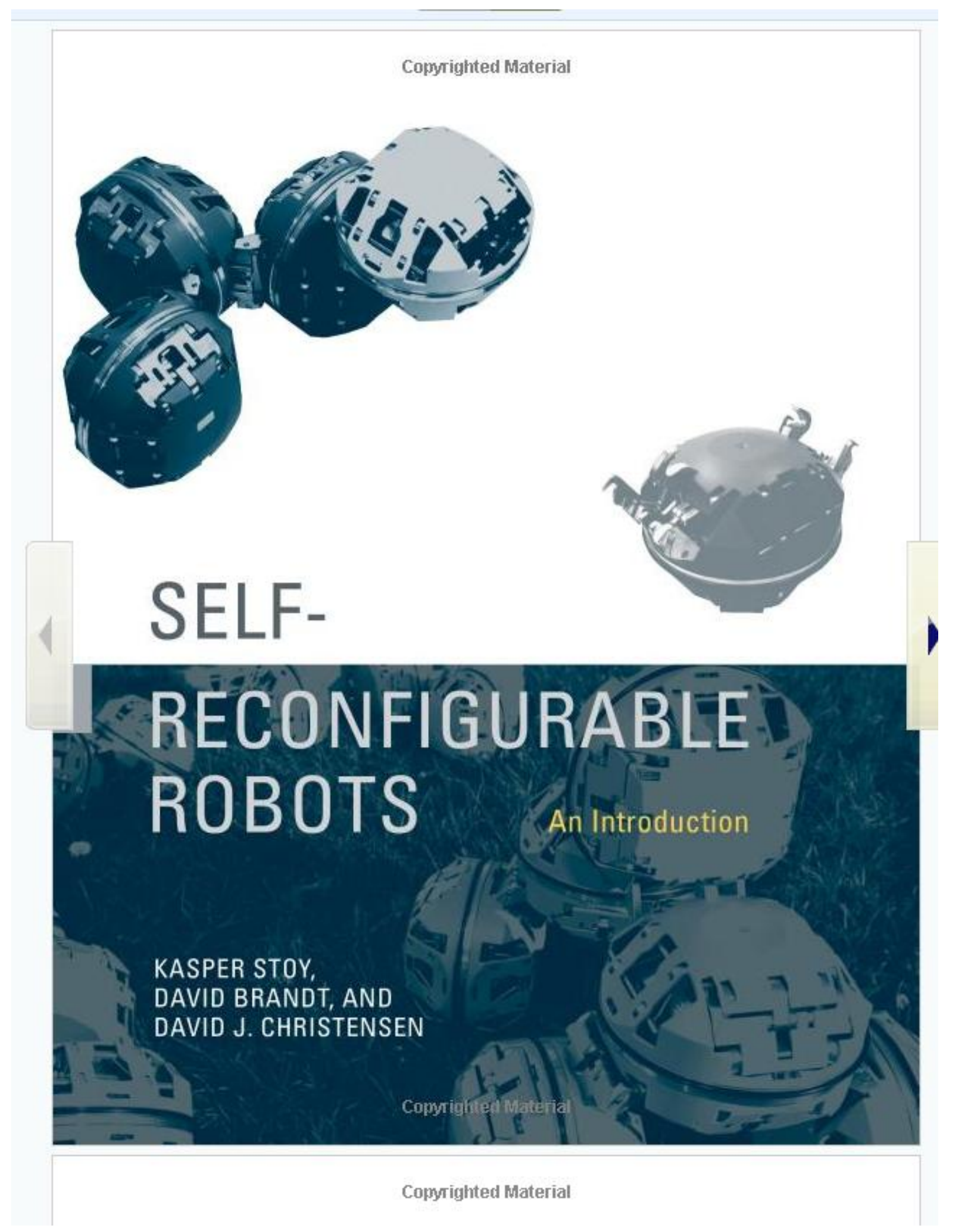




\section{Copyrighted Material}

Intelligent Robotics and Autonomous Agents

Edited by Ronald C. Arkin

For a complete list of the books published in this series, please see the back of this book.

Copyrighted Material

Copyrighted Material 
Copyrighted Material

Self-Reconfigurable Robots

An Introduction

Kasper Stoy

David Brandt

David J. Christensen

The MIT Press

Cambridge, Massachusetts

London, England

Copyrighted Material

Copyrighted Material 


\section{Copyrighted Material}

2010 Massachusetts Institute of Technology

All rights reserved. No part of this book may be reproduced in any form by any electronic or mechanical means (including photocopying, recording, or information storage and retrieval) without permission in writing from the publisher.

For information about special quantity discounts, please email special_sales@mitpress.mit.edu

This book was set in Times New Roman on $3 \mathrm{~B} 2$ by Asco Typesetters, Hong Kong.

Printed and bound in the United States of America.

Library of Congress Cataloging-in-Publication Data

Stoy, Kasper, 1973-

Self-reconfigurable robots : an introduction / Kasper Stoy, David Brandt, and David J. Christensen.

p. $\mathrm{cm} .-$ (Intelligent robotics and autonomous agents series)

Includes bibliographical references and index.

ISBN 978-0-262-01371-0 (hardcover ; alk. paper) 1. Robotics. 2. Robots. I. Brandt, David, 1979

II. Christensen, David J. III. Title.

TJ211.\$794 2010

$629.8^{\circ} 92-\mathrm{de} 22$

2009021060

$\begin{array}{llllllllll}10 & 9 & 8 & 7 & 6 & 5 & 4 & 3 & 2 & 1\end{array}$

Copyrighted Material

Copyrighted Material 
